\title{
Loop-mediated isothermal amplification (LAMP) for rapid detection of Renibacterium salmoninarum, the causative agent of bacterial kidney disease
}

\author{
Mona Saleh, Hatem Soliman, Mansour El-Matbouli* \\ Clinic for Fish and Reptiles, Faculty of Veterinary Medicine, Kaulbachstr. 37, University of Munich, 80539 Munich, Germany
}

\begin{abstract}
A loop-mediated isothermal amplification (LAMP) assay was developed for rapid, specific and sensitive detection of Renibacterium salmoninarum in $1 \mathrm{~h}$ without thermal cycling. A fragment of $R$. salmoninarum p57 gene was amplified at $63^{\circ} \mathrm{C}$ in the presence of Bst polymerase and a specially designed primer mixture. The specificity of the BKD-LAMP assay was demonstrated by the absence of any cross reaction with other bacterial strains, followed by restriction digestion of the amplified products. Detections of BKD-LAMP amplicons by visual inspection, agrose gel electrophoresis, and real-time monitoring using a turbidimeter were equivalently sensitive. The BKDLAMP assay has the sensitivity of the nested PCR method, and 10 times the sensitivity of one-round PCR assay. The lower detection limit of BKD-LAMP and nested PCR is $1 \mathrm{pg}$ genomic $R$. salmoninarum DNA, compared to $10 \mathrm{pg}$ genomic $R$. salmoninarum DNA for one-round PCR assay. In comparison to other available diagnostic methods, the BKD-LAMP assay is rapid, simple, sensitive, specific, and cost effective with a high potential for field application.
\end{abstract}

KEY WORDS: Renibacterium salmoninarum $\cdot$ BKD $\cdot$ LAMP $\cdot$ Diagnosis

Resale or republication not permitted without written consent of the publisher

\section{INTRODUCTION}

Bacterial kidney disease (BKD) is a systemic disease of fresh and salt water salmonids worldwide; the disease is caused by Renibacterium salmoninarum (Fryer \& Sanders 1981, Evenden et al. 1993, Bruno 2004). It is generally a chronic, granulomatous and often fatal infection, although acute disease may occur (Miriam et al. 1997). It causes mortality in all host age groups and poor growth rates in chronically infected fish (Bruno 2004). R. salmoninarum can be transmitted both horizontally among cohorts and vertically by intra-ovum inclusion (Evelyn et al. 1984, Balfry et al. 1996). BKD was first described in Atlantic salmon Salmo salar in Scotland (Mackie et al. 1933), then in rainbow trout Oncorhynchus mykiss from Massachusetts, USA (Belding \& Merril 1935). In Germany, BKD was first recorded in farmed salmon and trout by Hoffmann et al. (1984) and has since been reported elsewhere in Europe, Japan, South America and many states of the
USA. $R$. salmoninarum is a small, Gram-positive, nonmotile diplobacillus that has fastidious nutritional requirements (Austin et al. 1983, Daly \& Stevenson 1993, Teska 1994, Starliper et al. 1998). Acute BKD is characterized by dark colouration of the fish, bloody ascites, exophathalmia, and granulomatous lesions of internal organs such as the kidney, whereas asymptomatic carriers can complete an entire life cycle and successfully spawn (Fryer \& Lannan 1993). Control measures have been investigated to limit the spread of the disease; however, most have had limited success (Elliott et al. 1989, Moffitt 1992). To facilitate successful control of $\mathrm{BKD}$, there is a need for a series of diagnostic tests that can detect the bacterium during the different phases of the infection (White et al. 1995).

Bacteriological culture is the benchmark method for conventional diagnosis of BKD. However, due to the long incubation times ( 6 to $19 \mathrm{wk}$ at $15^{\circ} \mathrm{C}$ ) and the tedious process required for primary isolation of Reni- 
bacterium salmoninarum, culture is often impractical for routine diagnosis (Benediktsdottir et al. 1991). Alternate techniques have been developed for detection of the bacterium including direct and indirect fluorescent antibody assay (Bullock \& Stuckey 1975, Austin \& Austin 1993), and the enzyme-linked immunosorbent assay (ELISA) (Pascho et al. 1987, Jansson et al. 1996). These techniques also have some drawbacks as they are not sensitive enough to detect low levels of the pathogen in asymptomatic fish and, in the case of the fluorescent antibody assay, may give false positive reactions (Austin et al. 1985, Armstrong et al. 1989). Conversely, inconsistent results may arise with ELISA due to the variable quality of antibody lots and cross reactivity with other bacterial species (Scott \& Johnson 2001, Powell et al. 2005). To overcome the drawbacks of these methods, several polymerase chain reaction (PCR) assays have been developed for sensitive and rapid detection of BKD in infected fish tissues and eggs (Brown et al. 1994, Leon et al. 1994, Magnusson et al. 1994, Chase \& Pascho 1998, Powell et al. 2005, Chase et al. 2006, Rhodes et al 2006, Suzuki \& Sakai 2007).

Although PCR assays are powerful and sensitive tools for diagnosis of BKD, they require expensive equipment, precision thermocycling and laboratory training, which limits their use as routine diagnostic tools in the field.

Loop-mediated isothermal amplification (LAMP) is a technique developed recently to amplify nucleic acid under isothermal conditions. It offers a rapid, inexpensive and accurate tool for all life sciences, including diagnosis of pathogens and detection of genetic disorders (Notomi et al. 2000). Unlike PCR, LAMP does not require a denatured template, but depends on the high strand displacement activity of Bst polymerase (Nagamine et al. 2001). The technique employs a set of 4 specific primers that recognize 6 distinct nucleotide sequences of the target DNA. LAMP is initiated by an inner primer, which amplifies the sense and anti-sense strands of the target, then an outer primer displaces the amplified strand to give a single stranded DNA. This single-stranded DNA serves as a template for further DNA synthesis primed by the second inner and outer primers that hybridize to the ends of the target to produce a stem loop DNA structure (Notomi et al. 2000). Amplification proceeds in a cyclical order, each strand being displaced during elongation with the addition of new loops in each cycle. The final products are stem loop DNAs with several inverted repeats of the target and a cauliflower-like structure of multiple loops that arise from hybridization between alternately inverted repeats in the same strand. An additional set of 2 primers can accelerate the reaction (Nagamine et al. 2002).
Several means for visually detecting LAMP amplicons without agarose gel electrophoresis have been developed. One of these is the visual detection of magnesium pyrophosphate, a white precipitate that is produced during DNA amplification and which can be easily detected by the naked eye or by real time monitoring of turbidity in the reaction tube with a turbidimeter (Mori et al. 2001, 2004). Alternatively, LAMP products can be monitored by a colour change resulting from addition of an intercalating DNA dye such as SYBR Green I gel stain (Soliman \& El-Matbouli 2005) or fluorescent detection reagent (FDR) (Yoda et al. 2007). Fluorescently labelled probe and cationic polymers such as low molecular weight polyethylenimine (PEI) have also been used for visual detection of LAMP amplicons (Mori et al. 2006). In aquaculture, LAMP assays have been developed for several fish and shellfish pathogens including white spot syndrome virus (Kono et al. 2004), Edwardsiella tarda (Savan et al. 2004), E. ictaluri (Yeh et al. 2005), Flavobacterium columnare (Yeh et al 2006), yellow head virus (Mekata et al. 2006), iridovirus (Caipang et al. 2004), infectious hematopoietic necrosis virus (Gunimaladevi et al. 2004), koi herpes virus (Gunimaladevi et al. 2005) and Nocardia seriolae (Itano et al. 2005). In our laboratory, we have designed several LAMP assays to detect the pathogens Tetracapsuloides bryosalmonae, Мухоbolus cerebralis, koi herpes virus (CyHV-3), viral hemorrhagic septicaemia (VHS), Thelohania contejeani (El-Matbouli \& Soliman 2005a,b, 2006, Soliman \& El- Matbouli 2005, 2006).

The aim of the current work was to develop an accelerated, cost effective, specific and sensitive LAMP assay with high potential for field diagnosis of BKD in salmonids.

\section{MATERIAL AND METHODS}

Bacterial strains. Renibacterium salmoninarum was kindly provided by S. Braune, Niedersächsisches Landesamt für Verbraucherschutz und Lebensmittelsicherheit, Veterinärinstitut Hannover, Germany. The bacteria was cultured on selective kidney disease medium (SKDM) agar (Austin et al. 1983). The purity of the culture was tested by Gram stain and confirmed by biochemical tests.

The other bacterial strains, viz. Aeromonas salmonicida, A. sobria, Yersinia ruckeri, Flavobacterium columnare, and Pseudomonas aeroginosa were from our Clinic of Fish and Reptiles (formerly Institute of Zoology, Fish Biology and Fish Diseases), University of Munich, Germany. Each strain was propagated on its specific medium and then tested by Gram stain and biochemically for confirmation of identity. 
DNA extraction. Bacterial genomic DNA was extracted using a QIAamp ${ }^{\circledR}$ DNA mini kit (Qiagen). Bacterial cells were harvested in a micro-centrifuge tube by centrifugation at $5000 \times g$ for $10 \mathrm{~min}$. Cell pellets were re-suspended in $180 \mu \mathrm{l}$ lysis buffer $\left(20 \mathrm{mg} \mathrm{ml}^{-1}\right.$ lysozyme, $20 \mathrm{mM}$ Tris- $\mathrm{HCl}$, $\mathrm{pH}$ 8.0, 2 mM EDTA, $1.2 \%$ Triton) and incubated at $37^{\circ} \mathrm{C}$ for $30 \mathrm{~min}$. Proteinase $\mathrm{K}$ and buffer AL were then added and mixed by vortexing. After $30 \mathrm{~min}$ incubation at $56^{\circ} \mathrm{C}$, ethanol was added and thoroughly mixed to yield a homogenous solution. DNA was then extracted as per manufacturer's instructions. DNA was extracted from kidney tissue samples using a QIAamp ${ }^{\circledR}$ DNA mini kit. Kidney tissues were incubated with the lysozyme buffer (80 mg ml ${ }^{-1}$ lysozyme, $80 \mathrm{mM}$ Tris- $\mathrm{HCl}, \mathrm{pH} 8.0,8 \mathrm{mM}$ EDTA, $4.8 \%$ Triton) at $37^{\circ} \mathrm{C}$ for $1 \mathrm{~h}$ after the initial lysis step. DNA was then extracted according to the manufacturer's instructions following the animal tissues protocol.

Oligonucleotide primers. LAMP primers and fluorescently labelled probe were designed based on the major soluble antigen protein p57 encoding gene of Renibacterium salmoninarum (GenBank accession number AF123890) using LAMP primer design software (PrimerExplorer Ver.4). Five primers were used for LAMP assay: 2 outer primers (F3 and B3), 2 inner primers (Forward Inner Primer [FIP] and Backward Inner Primer [BIP]) and loop forward primer (LF) (Table 1). The FIP comprised an F1c sequence complementary to F1, a TTTT linker, and an F2 sequence. The BIP consisted of a B1c sequence complementary to B1, a TTTT Linker and a B2 sequence. After modification of the 3 ' end with fluorescein isocyanate, the loop forward primer LF was also used as Oligo DNA Probe (ODP).

Table 1. Details of oligonucleotide primers used for BKD-LAMP assay, PCR and nested PCR assay

\begin{tabular}{|c|c|c|}
\hline $\begin{array}{l}\text { Primer } \\
\text { name }\end{array}$ & Length & Sequence $\left(5^{\prime}-3^{\prime}\right)$ \\
\hline F3 & 20-mer & GCCCGGTAGAGGTTAAAGTC \\
\hline B3 & 18-mer & CGGAACCAGCATTTGGCT \\
\hline FIB & 43-mer & $\begin{array}{l}\text { GGAGTTGCTCCATCTGGTGCA TTTT } \\
\text { CCGCAACAGCA ACTGACA }\end{array}$ \\
\hline BIP & 45-mer & $\begin{array}{l}\text { CTGGTAAATGGTGGTCTGGCGA TTTT } \\
\text { CCGCAACAGC AACTGACA }\end{array}$ \\
\hline F Loop & 21-mer & GTGTTGGTCACTACCCACGTA \\
\hline ODP & 21-mer & $\begin{array}{l}\text { GTGTTGGTCACTACCCACGTA- } \\
\text { Fluorescein isocyanate }\end{array}$ \\
\hline FL7 & 20-mer & CGCAGGAGGACCAGTTGCAG \\
\hline RL5 & 20-mer & TCCGTTCCCGGTTTGTCTCC \\
\hline P3 & 19-mer & AGCTTCGCAAGGTGAAGGG \\
\hline P4 & 25-mer & АTTCTTCCACTTCAACAGTACAAGG \\
\hline M21 & 21-mer & GCAACAGGTTTATTTGCCGGG \\
\hline M38 & 22-mer & CATTATCGTTACACCCGAAACC \\
\hline
\end{tabular}

Specific primers FL7 and RL5 for one-round PCR and P3, P4, M21, M38 for nested PCR (Table 1) were used to amplify $372 \mathrm{bp}$ and 383bp DNA fragments of the major soluble antigen p57 encoding gene of Renibacterium salmoninarum, respectively, following Miriam et al. (1997) and Pascho et al. (1998).

BKD-LAMP assay. To optimise the LAMP assay, different concentrations of the primers, $\mathrm{MgSO}_{4}$ and Bst DNA polymerase, different incubation temperatures and different times were evaluated. The optimized BKD-LAMP assay was carried out in a $25 \mu \mathrm{l}$ reaction volume contained: $1 \times$ Thermopol buffer $(20 \mathrm{mM}$ Tris$\mathrm{HCl} \mathrm{pH} 8.8,10 \mathrm{mM} \mathrm{KCl}, 4.5 \mathrm{mM} \mathrm{MgSO}{ }_{4}, 10 \mathrm{mM}$ $\left(\mathrm{NH}_{4}\right)_{2} \mathrm{SO}_{4}, \quad 0.1 \%$ Triton X-100) (New England BioLabs), 1.6 M betaine (Sigma-Aldrich), $1.4 \mathrm{mM}$ of each dNTPs (Sigma-Aldrich), 60 pmol each of inner primers FIP and BIP, 5 pmol each of outer primers F3 and B3, $30 \mathrm{pmol}$ of LF primer, 8U Bst DNA polymerase (New England BioLabs), $2 \mu \mathrm{l}$ of DNA template and PCR grade water to $25 \mu \mathrm{l}$. The mixture was incubated at $63^{\circ} \mathrm{C}$ in a Loopamp real-time turbidimeter (LA-200, Teramecs) for $60 \mathrm{~min}$ and then heated to $85^{\circ} \mathrm{C}$ for $2 \mathrm{~min}$ to terminate the reaction. Reaction mix without DNA template was included as a negative control.

PCR amplification. One-round PCR amplification was performed in a $50 \mu \mathrm{l}$ reaction volume which comprised $46.5 \mu$ of $1.1 \times$ ready mix PCR Master mix (ABgene) (containing: $75 \mathrm{mM}$ Tris- $\mathrm{HCl}$ (pH 8.8), $20 \mathrm{mM}\left(\mathrm{NH}_{4}\right)_{2} \mathrm{SO}_{4}, 1.5 \mathrm{mM} \mathrm{MgCl}, 0.01 \%$ Tween-20, $0.2 \mathrm{mM}$ each of nucleotide triphosphate, $1.25 \mathrm{U}$ Thermoprime Plus DNA Polymerase, red dye for electrophoresis), 20 pmol of each forward and reverse primers and $1.5 \mu \mathrm{l}$ of DNA template. The reaction mixture was subjected to the following cycling profile: $94^{\circ} \mathrm{C}$ for $2 \mathrm{~min}$, followed by 5 cycles of $94^{\circ} \mathrm{C}$ for $15 \mathrm{~s}$ (denaturating), $63^{\circ} \mathrm{C}$ for $2 \mathrm{~min}$ (annealing), and $72^{\circ} \mathrm{C}$ for $15 \mathrm{~s}$ (extending) and then 35 cycles of $94^{\circ} \mathrm{C}$ for $15 \mathrm{~s}$, $63^{\circ} \mathrm{C}$ for $15 \mathrm{~s}$, and $72^{\circ} \mathrm{C}$ for $15 \mathrm{~s}$ and a final extension step at $72^{\circ} \mathrm{C}$ for $1 \mathrm{~min}$. DNA template was omitted from a reaction mix and used as a negative control.

Nested PCR amplification. In the first round, amplification was carried out in a $50 \mu$ l reaction volume which comprised $43 \mu \mathrm{l}$ of $1.1 \times$ ready mix PCR Master mix (ABgene) (containing: $75 \mathrm{mM}$ Tris- $\mathrm{HCl}(\mathrm{pH} 8.8)$, $20 \mathrm{mM}\left(\mathrm{NH}_{4}\right)_{2} \mathrm{SO}_{4}, 1.5 \mathrm{mM} \mathrm{MgCl}, 0.01 \%$ Tween-20, $0.2 \mathrm{mM}$ each of nucleotide triphosphate, $1.25 \mathrm{U}$ Thermoprime Plus DNA Polymerase, red dye for electrophoresis), $0.2 \mathrm{mM}$ of each P3 and M21 primers and $5 \mu \mathrm{l}$ DNA template. In the second round, amplification was performed in a $50 \mu$ reaction volume, which contained $47 \mu$ of $1.1 \times$ ready mix PCR Master mix, $0.2 \mathrm{mM}$ of each P4 and M38 primers and $1 \mu$ of the first round PCR product as a DNA template. Both reaction mixtures were subjected to the following cycling profile: $94^{\circ} \mathrm{C}$ for $5 \mathrm{~min}$, followed by 30 cycles of $94^{\circ} \mathrm{C}$ for $30 \mathrm{~s}$, 
$60^{\circ} \mathrm{C}$ for $30 \mathrm{~s}$, and $72^{\circ} \mathrm{C}$ for $1 \mathrm{~min}$ and a final extension step at $72^{\circ} \mathrm{C}$ for $10 \mathrm{~min}$. DNA template was omitted from a reaction mix and used as a negative reaction control.

Detection of the amplification products. LAMP products were visually detected either by using $1 \mu \mathrm{l}$ of Fluorescent Detection Reagent (FDR, Eiken Chemical) added to the reaction mixture before incubation at $63^{\circ} \mathrm{C}$, or by addition of $1 \mu \mathrm{l}$ of $1: 10$ diluted SYBR Green I nucleic acid gel stain at $10000 \times$ concentration in DMSO (Cambrex BioScience) to the mixture after reaction termination and observation of the colour changes of the reaction mixture. For detection with the fluorescently labelled probe, $0.2 \mu \mathrm{mol}$ of low molecular weight (MW 600) polyethylenimine (PEI) (Wako Chemical) was added to the reaction mixture after centrifugation for $10 \mathrm{~s}$ at $6000 \mathrm{rpm}$ to form an insoluble PEI-amplicon complex containing the fluorescently labelled probe, which was precipitated by additional centrifugation at $6000 \mathrm{rpm}$ for $10 \mathrm{~s}$. Reaction tubes were then visualised under a conventional UV illuminator or by fluorescence microscopy. Alternatively, increased turbidity derived from magnesium pyrophosphate byproduct was monitored using a real-time turbidimeter (LA-200, Teramecs). An assay was regarded as positive when turbidity reached the threshold value fixed at 0.1 , which is double the average turbidity value of several replicate negative controls. For electrophoretic analysis, LAMP, PCR and nested PCR amplification products were analysed by gel electrophoresis on $2 \%$ agarose in Tris acetate-EDTA buffer, TAE, (0.04M Tris acetate, $1 \mathrm{mM}$ EDTA), stained with GelRed ${ }^{\mathrm{TM}}$ Nucleic Acid Gel Stain, $10000 \times$ in water (BIOTREND Chemikalien) and then visualised under UV light. A TrackIt ${ }^{\mathrm{TM}} 100 \mathrm{bp}$ DNA ladder (Invitrogen) was used as molecular weight marker.

Restriction analysis of the LAMP products. To confirm the structure of the LAMP amplicons, some of the reaction products were purified using a High Pure PCR purification kit (Roche Molecular Biochemicals) and then subjected to digestion with ECORV restriction enzyme (New England BioLabs). Fragment sizes were analyzed by electrophoresis in $2 \%$ agarose gels followed by staining with GelRed ${ }^{\mathrm{TM}}$ Nucleic Acid Gel Stain $10000 \times$ in water (BIOTREND Chemikalien). A TrackIt ${ }^{\mathrm{TM}} 100 \mathrm{bp}$ DNA ladder (Invitrogen) was used as molecular weight marker.

BKD-LAMP assay specificity. The specificity of the BKD-LAMP assay for Renibacterium salmoninarum DNA was evaluated by testing it against DNA from a suite of bacterial strains, viz. Aeromonas salmonicida, Aeromonas sobria, Pseudomonas aeruginosa, Yersinia ruckeri and Flavobacterium columnare. DNA from non-infected fish tissues was used to determine any non-specific amplification, while a no template control was used as a negative reaction control.

Sensitivity of the BKD-LAMP assay. The sensitivity of the assay was assessed by testing 10 -fold serial dilutions of $1 \mu \mathrm{g}$ genomic Renibacterium salmoninarum DNA in comparisons with one-round and nested PCR assays. Reaction mix without DNA template was included as a negative reaction control. BKD-LAMP amplification products were analysed visually and by agarose gel electrophoresis.

Applicability of the BKD-LAMP assay. The feasibility of using the BKD-LAMP assay to detect the Renibacterium salmoninarum DNA in clinical specimens was evaluated by testing 20 rainbow trout kidney samples infected with BKD and 6 uninfected kidney samples from our clinic's diagnostic material. The samples were tested by both BKD-LAMP assay and PCR assay. Reaction mix without DNA template was included as a negative control.

\section{RESULTS}

The optimized BKD-LAMP assay successfully amplified the target sequence of the Renibacterium salmoninarum major soluble antigen p57 gene as demonstrated by agrose gel electrophoresis and real time monitoring of turbidity. The amplified products were observed as a ladder-like pattern on the gel (Fig. 1). The specificity of the LAMP products was confirmed by restriction endonuclease digestion with ECoRV, which produced 90 and $120 \mathrm{bp}$ bands instead of the ladder-like pattern that disappeared (Fig. 1). No amplification product was detected in the negative controls.

The BKD-LAMP products appeared green after addition of SYBR Green I dye, whereas the original orange colour of SYBR Green I did not change in the negative control tubes (Fig. 2A). Positive LAMP reactions using FDR emitted strong green fluorescence when exposed to UV light, while negative controls were unchanged (Fig. 2B); colour change was also observable with the naked eye under normal visible light. When performed with a fluorescently labelled probe, the pellets formed with positive reactions emitted green fluorescence, while neither pellets nor fluorescence was observed in the negative control tubes (Fig. 2C). The BKD-LAMP assay specifically amplified DNA extracted from Renibacterium salmoninarum. No amplification products were detected with the DNA from other tested bacterial strains, non infected fish tissues or no-template control. The detection limit of the BKD-LAMP and nested PCR assays for $R$. salmoninarum major soluble antigen protein p57 encoding gene was about 1 pg per reaction (dilution $10^{-6}$ ), while the detection limit of the one-round PCR assay was 


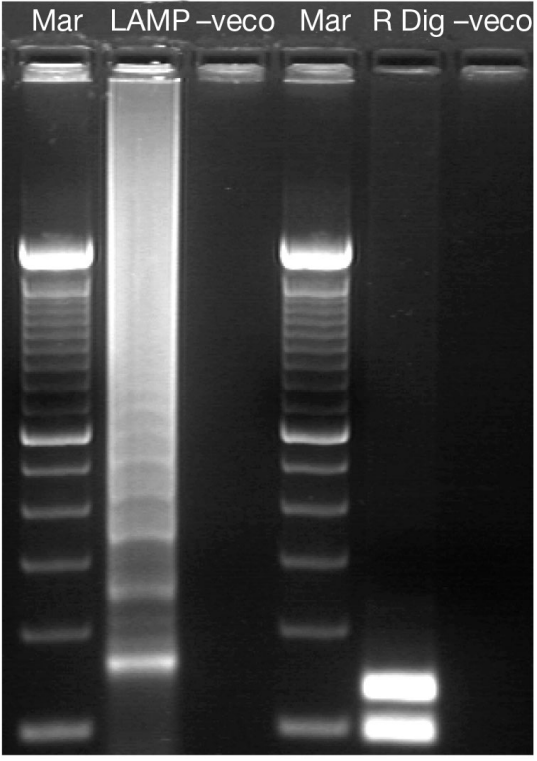

Fig. 1. Renibacterium salmoninarum. Loop-mediated isothermal amplification (LAMP) products and restriction analysis of $R$. salmoninarum LAMP product with ECoRV enzyme. Lane Mar: 100-base-pair DNA ladder; lane LAMP: amplified $R$. salmoninarum LAMP product showing a ladder-like pattern; lane R Dig: $R$. salmoninarum LAMP product digested with ECORV with production of $90 \mathrm{bp}$ and 120 bp bands; lane-veco: no template control

about $10 \mathrm{pg}$ per reaction (dilution $10^{-5}$ ) (Fig. 3). The BKD-LAMP assay successfully detected $R$. salmoninarum DNA from 20 infected kidney samples, which were also shown positive by PCR and nested PCR. Kidney samples from all 6 uninfected fish and the no template control were negative (Fig. 4).

\section{DISCUSSION}

Rapid detection of Renibacterium salmoninarum is fundamental to control measures for preventing the spread of the BKD. Although PCR assays are powerful, sensitive and efficient tools for diagnosis of BKD (Pascho et al. 2002), the requirement of a thermalcycler, an expensive and sophisticated instrument, has limited their application for field diagnostic tests.

In this study a one-step, real-time LAMP assay was developed for rapid diagnosis of BKD. The amplification is performed in a single tube and requires only a simple water bath or heating block to incubate the reaction mixture. Design of appropriate primers for LAMP is key for optimization of the assay because it requires 4 primers that recognize 6 distinct regions on the target DNA (Enosawa et al. 2003). For detection of Renibacterium salmoninarum, p57 protein is a good marker for active infection as it is the predominant cell
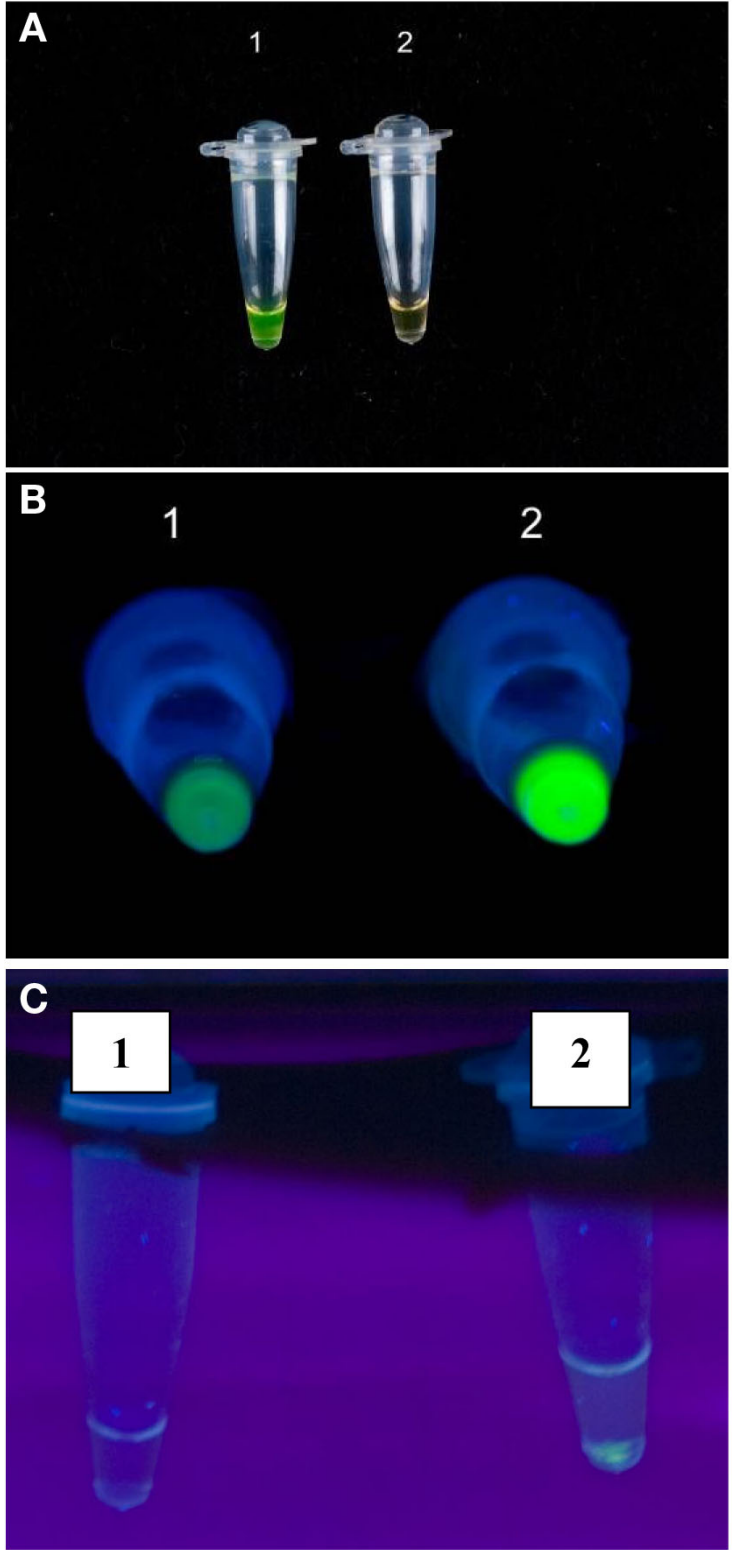

Fig. 2. Visual detection of BKD-LAMP product by using different naked eye detection methods: (A) Positive sample (1) with green colour using SYBR green I stain, and (2) negative sample with orange colour. (B) Negative sample (1) using FDR (no strong green fluorescence) and (2) positive sample with strong green fluorescence. (C) Negative reaction (1) using fluoresceinisocyanate-labelled probe (no pellet, no green fluorescence) and (2) positive reaction (pellet is fluorescing green)

surface and secreted protein produced by the bacterium (Getchell et al. 1985, Wiens \& Kaattari 1989, Grayson et al. 1999). Consequently, most molecular diagnostic assays for $R$. salmoninarum are based on detection of the gene which codes for p57 (Brown et al. 1995, Miriam et al. 1997, Chase \& Pascho 1998, Cook \& Lynch 1999). We designed multiple LAMP primers 

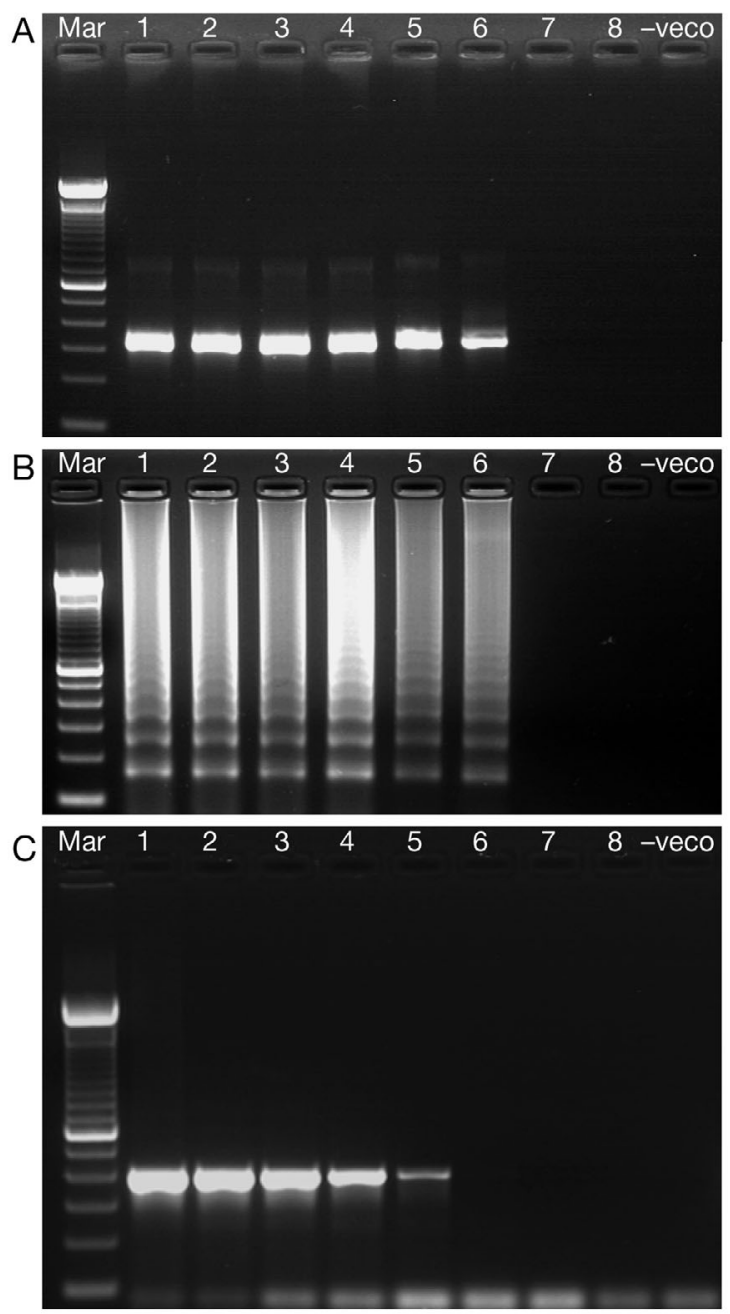

Fig. 3. (A) Sensitivity of nested PCR assay in detecting $383 \mathrm{bp}$ Renibacterium salmoninarum DNA fragment. (B) Sensitivity of BKD-LAMP primers detecting $R$. salmoninarum DNA. (C) Sensitivity of one-round PCR assay detecting $372 \mathrm{bp} R$. salmoninarum DNA fragment. Lanes Mar: 100-base-pair DNA ladder; lanes 1-8: 10-fold serial dilutions of $1 \mu \mathrm{g} R$. salmoninarum DNA from $10^{-1}-10^{-8}$; lanes -veco: no template control

based on the major soluble antigen gene encoding p57. All primer combinations were able to detect $R$. salmoninarum DNA, but the optimal LAMP primer set used in this assay had highest sensitivity and specificity for detection of the target sequence. The BKD-LAMP assay was optimized to amplify $R$. salmoninarum DNA in $1 \mathrm{~h}$ at $63^{\circ} \mathrm{C}$ using a set of 4 or 5 primers. The amplification products when electrophoresed on a gel appeared in a ladder-like pattern, which arose from the formation of a mixture of stem loop DNAs of various stem lengths and cauliflower-like structures with multiple loops formed by annealing between alternately inverted repeats of the target sequence in the same strand (Thai et al. 2004). The identity of the amplicons was confirmed by ECORV restriction enzyme digest.
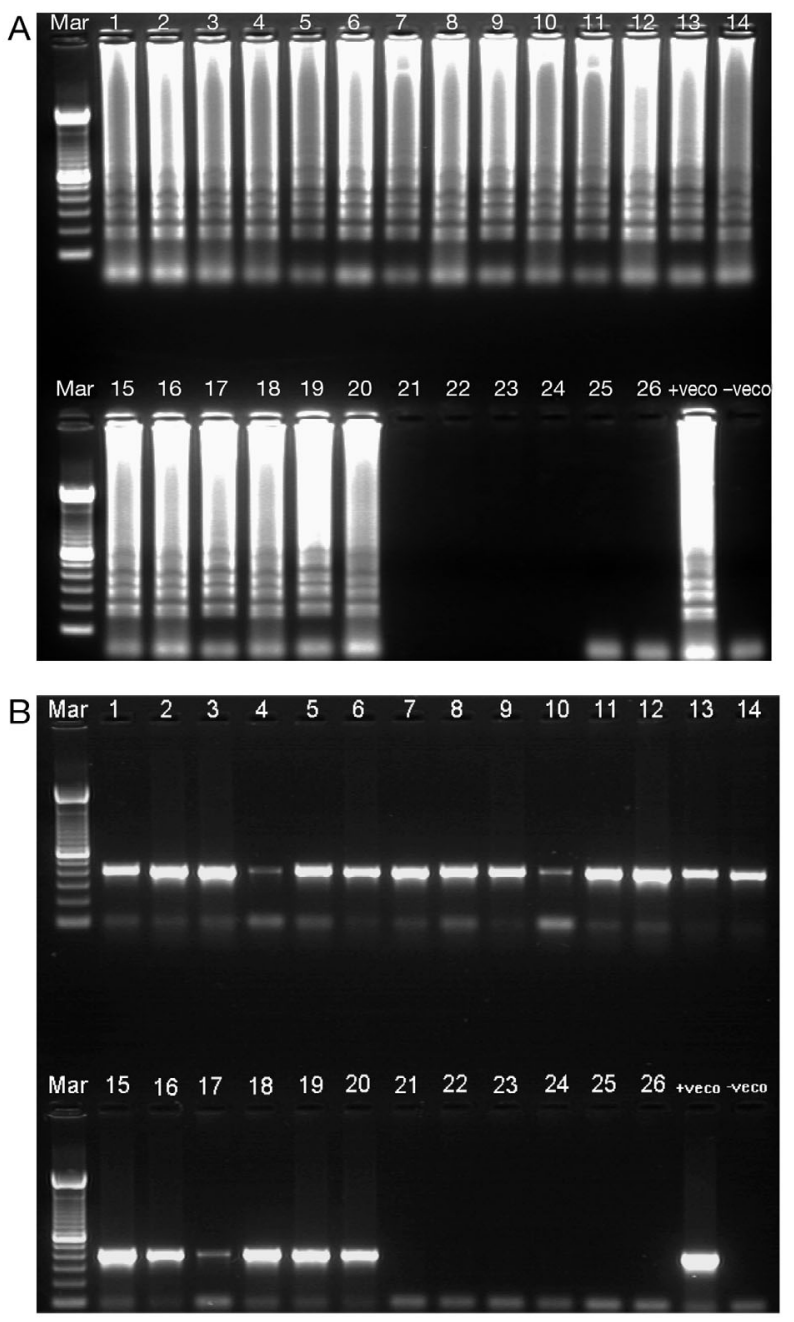

Fig. 4. (A) Feasibility of BKD-LAMP assay for detection of Renibacterium salmoninarum DNA from 20 infected kidney samples, with no amplification products from uninfected kidney samples. (B) BKD-PCR assay demonstrating the $372 \mathrm{bp}$ fragment of $R$. salmoninarum DNA from 20 infected kidney samples, with no amplifications products from uninfected kidney samples. Lanes Mar: 100-base-pair DNA ladder; lanes 1-20: DNA from infected kidney samples; lanes 21-26: DNA from uninfected kidney samples; lanes +veco: DNA from $R$. salmoninarum as a positive control; lanes -veco: no template control

The LAMP method was both highly specific and highly efficient, and, since it uses 4 primers that recognize 6 distinct sequences on the target DNA, its specificity is extremely high (Notomi et al. 2000). The specificity of the BKD-LAMP assay was confirmed by amplification of DNA from Renibacterium salmoninarum only and no amplification of DNA from a suite of other bacterial strains. The LAMP method also has an extremely high amplification efficiency due in part to its isothermal nature; there is no requirement for temperature changes to facilitate enzyme function or 
inhibit the reaction during later stages of amplification, a typical problem with PCR (Notomi et al. 2000, Nagamine et al. 2001). The LAMP reaction produces a large amount of the byproduct magnesium pyrophosphate, which leads to turbidity in the reaction mixture. As the increase in turbidity correlates with the amount of DNA amplified, the LAMP reaction can be monitored in real-time with a turbidimeter (Mori et al. 2001). Also, the reaction can be monitored visually with SYBR Green I gel stain, which has high binding affinity to double stranded DNA, and changes from orange to green as the LAMP amplicons are produced (Karleson et al. 1995, Iwamoto et al. 2003). To avoid any contamination that may have arisen from opening the LAMP reaction tube to add SYBR Green, we tested a different visual indicator, FDR, which was added with the initial reagents. Calcein in the FDR combines with manganese and quenches it, but as pyrophosphate ions produced by the LAMP reaction preferentially bind with calcein and displace manganese, fluorescence occurs, indicating production of the target amplicons (Imai et al. 2007, Yoda et al. 2007). A third method of BKD-LAMP amplification product visualisation was the addition of cationic polymers to the reaction mixture. Low molecular weight PEI was used to form an insoluble PEI-LAMP product complex which contained the hybridized fluorescently labelled probe. PEI was selected because it is widely used as a nucleic acid precipitant for nucleic acid purification (Cordes et al. 1990). It also has the ability to form an insoluble complex with high molecular weight DNAs like LAMP amplification products, but does not form insoluble complexes with single-stranded anionic polymers of low molecular weight (Mori et al. 2006). All samples that assayed positive by visual inspection were also positive by gel electrophoresis.

The sensitivity of the BKD-LAMP assay was compared with one-round PCR and the nested-PCR assays recommended by OIE for diagnosis of BKD. BKDLAMP assay had sensitivity equivalent to that of nested PCR and it was 10-times more sensitive than the one-round PCR assay. BKD-LAMP requires only a single tube (so there is negligible possibility of contamination), is complete within $1 \mathrm{~h}$ (compared to $5 \mathrm{~h}$ for nested PCR), needs only a simple water bath or heating block, does not need post-amplification processing by electrophoresis and is as sensitive as nested PCR assay. This higher sensitivity and superior performance should allow the BKD-LAMP assay to detect small amounts of Renibacterium salmoninarum DNA in infected samples, which will improve diagnosis of BKD in salmonids. We successfully detected R. salmoninarum DNA in samples of infected fish kidney and hence demonstrated the use of the BKD-LAMP assay on clinical specimens.
Since positive LAMP assay results can be seen by the unaided eye, rather than by electrophoresis, and denaturation of the template is not necessary, the LAMP reaction can be carried out in a simple water bath or heating block in the field. Additionally, the use of cheaper or disposable equipment for the assay would overcome difficulties in decontaminating instruments such as thermocyclers that would need to be transferred between premises for PCR assays (Dukes et al. 2006).

In conclusion, the BKD-LAMP assay represents a rapid, specific, sensitive and cost-effective technique with high potential for field deployment. The assay can be used in fish farms and small laboratories for more rapid detection of $\mathrm{BKD}$, which would allow accelerated instigation of control measures.

Acknowledgements. We thank S. Braune, Niedersächsisches Landesamt für Verbraucherschutz und Lebensmittelsicherheit, Veterinärinstitut Hannover, Germany for suppling the Renibacterium salmoninarum reference strain. We also thank S. Frischmann, Mast Diagnostica Laboratoriumspräparate $\mathrm{GmbH}$, Reinfeld, Germany for providing us with the LA-200 real-time turbidimeter.

\section{LITERATURE CITED}

Armstrong RD, Martin SW, Evelyn TP, Hichs B, Dorward WJ, Ferguson HW (1989) A field evaluation of an indirect fluorescent antibody based broodstock screening test used to control the vertical transmission of Renibacterium salmoninarum in Chinook salmon Oncorhynchus tshawytscha. Can J Vet Res 53:385-389

Austin B, Austin DA (1993) Bacterial fish pathogens: disease in farmed and wild fish, 2nd edn. Ellis Horwood, Chichester

Austin B, Embley TM, Goodfellow M (1983) Selective isolation of Renibacterium salmoninarum. FEMS Microbiol Lett 17:111-114

Austin B, Bucke D, Feist S, Raymant J (1985) A false positive reaction in the indirect fluorescent antibody test for Renibacterium salmoninarum with a 'coryneform' organism. Bull Eur Assoc Fish Pathol 5:8-9

Balfry SK, Albright LJ, Evelyn TPT (1996) Horizontal transfer of Renibacterium salmoninarum among farmed salmonids via the fecal-oral route. Dis Aquat Org 25:63-69

> Belding DL, Merril B (1935) A preliminary report upon a hatchery disease of the salmonidae. Trans Am Fish Soc 65:76-84

Benediktsdottir E, Helgason S, Gudmundsdottir S (1991) Incubation time for the cultivation of Renibacterium salmoninarum from Atlantic salmon, Salmo salar L., broodfish. J Fish Dis 14:97-102

Brown LL, Iwama GK, Evelyn TPT, Nelson WS, Levine RP (1994) Use of the polymerase chain reaction (PCR) to detect DNA from Renibacterium salmoninarum within individual salmonid eggs. Dis Aquat Org 18:165-171

> Brown LL, Evelyn TPT, Iwama GK, Nelson WS, Levine RP (1995) Bacterial species other than $R$. salmoninarum cross react with antisera against Renibacterium salmoninarum but are negative for the p57 gene of $R$. salmoninarum as 
detected by the polymerase chain reaction. Dis Aquat Org 21:227-231

Bruno DW (2004) Prevalence and diagnosis of bacterial kidney disease (BKD) in Scotland between 1990 and 2002. Dis Aquat Org 59:125-130

Bullock GL, Stuckey HM (1975) Fluorescent antibody identification and detection of the corynebacterium causing kidney disease of salmonids. J Fish Res Board Can 32: 224-227

Caipang CMA, Haraguchi I, Ohira T, Hirono I, Aoki T (2004) Rapid detection of a fish iridovirus using loop-mediated isothermal amplification (LAMP). J Virol Methods 121: 155-161

Chase DM, Pascho RJ (1998) Development of a nested polymerase chain reaction for amplification of the p57 gene of Renibacterium salmoninarum that provides a highly sensitive method for detection of the bacterium in salmonid kidney. Dis Aquat Org 34:223-229

Chase DM, Elliot DG, Pascho RJ (2006) Detection and quantification of Renibacterium salmoninarum DNA in salmonid tissues by real-time quantitative polymerase chain reaction analysis. J Vet Diagn Invest 18:375-380

$>$ Cook M, Lynch WH (1999) A sensitive nested transcriptase PCR assay to detect viable cells of the fish pathogen Renibacterium salmoninarum in Atlantic salmon (Salmo salar L.). Appl Environ Microbiol 65:3042-3047

> Cordes RM, Siims WB, Glatz CE (1990) Precipitation of nucleic acids with poly (ethyleneimine). Biotechnol Prog 6: 283-285

> Daly JG, Stevenson RMW (1993) Nutritional requirements of Renibacterium salmoninarum on agar and in broth media. Appl Environ Microbiol 59:2178-2183

- Dukes JP, King DP, Alexanderson S (2006) Novel reverse transcription loop-mediated isothermal amplification for rapid detection of foot-and-mooth disease. Arch Virol 151: 1093-1106

El-Matbouli M, Soliman H (2005a) Rapid diagnosis of Tetracapsuloides bryosalmonae, the causative agent of proliferative kidney disease (PKD) in salmonid fish by a novel DNA amplification method, loop mediated isothermal amplification (LAMP). Parasitol Res 96:277-284

El-Matbouli M, Soliman H (2005b) Development of a rapid assay for diagnosis of Myxobolus cerebralis in fish and oligochaetes using loop-mediated isothermal amplification. J Fish Dis 28:549-557

El-Matbouli M, Soliman H (2006) Development and evaluation of two molecular diagnostic methods for detection of Thelohania contejeani (Microsporidia), the causative agent of porcelain disease in crayfish. Dis Aquat Org 69: 205-211

Elliott DG, Pascho RJ, Bullock GL (1989) Developments in the control of bacterial kidney disease of salmonid fishes. Dis Aquat Org 6:201-215

Enosawa M, Kageyama S, Sawai K, Watanabe K and others (2003) Use of loop-mediated isothermal amplification of the IS900 sequence for rapid detection of cultured Mycobacterium avium subsp. paratuberculosis. J Clin Microbiol 41:4359-4365

Evelyn TPT, Ketcheson JE, Prosperi-Porta L (1984) Further evidence for the presence of Renibacterium salmoninarum in salmonid eggs and for the failure of povidine-iodine to reduce the intra-ovum infection in water-hardened eggs. J Fish Dis 7:173-182

- Evenden AJ, Grayson TH, Gilpin ML, Munn CB (1993) Renibacterium salmoninarum and bacterial kidney diseasethe unfinished jigsaw. Annu Rev Fish Dis 3:87-104

Fryer JL, Lannan CN (1993) The history and current status of
Renibacterium salmoninarum, the causative agent of bacterial kidney disease in Pacific salmon. Fish Res 17:15-33

Fryer JL, Sanders JE (1981) Bacterial kidney disease of salmonid fish. Annu Rev Microbiol 35:273-298

Getchell RG, Rohovec JS, Fryer JL (1985) Comparison of Renibacterium salmoninarum isolates by antigenic analysis. Fish Pathol 20:149-159

Grayson TH, Cooper LF, Atienzar FA, Knowles MR, Gilpin ML (1999) Molecular differentiation of Renibacterium salmoninarum isolates from worldwide locations. Appl Environ Microbiol 65:961-968

- Gunimaladevi I, Kono T, Venugopal MN, Sakai M (2004) Detection of koi herpesvirus in common carp, Cyprinus carpio $L$., by loop-mediated isothermal amplification. J Fish Dis 27:583-589

$>$ Gunimaladevi I, Kono T, LaPatra SE, Sakai M (2005) A loop mediated isothermal amplification (LAMP) method for detection of infectious hematopoietic necrosis virus (IHNV) in rainbow trout (Oncorhynchus mykiss). Arch Virol 150:899-909

Hoffmann R, Popp Wand S, van de Graaff S (1984) Atypical BKD predominantly causing ocular and skin lesions. Bull Eur Assoc Fish Pathol 4:7-9

Imai M, Ninomiya A, Minekawa $\mathrm{H}$, Notomi $\mathrm{T}$ and others (2007) Rapid diagnosis of H5N1 avian influenza virus infection by newly developed influenza H5 hemagglutinin gene-specific loop-mediated isothermal amplification method. J Virol Methods 141:173-180

> Itano T, Kawakami H, Kono T, Sakai M (2006) Detection of fish nocardiosis by loop-mediated isothermal amplification. J Appl Microbiol 100:1381-1387

- Iwamoto T, Sonobe T, Hayashi K (2003) Loop-mediated isothermal amplification of Mycobacterium tuberculosis complex, $M$. avium, and $M$. intracellulare in sputum samples. J Clin Microbiol 41:2616-2622

> Jansson E, Hongslo T, Höglund J, Ljungberg O (1996) Comparative evalution of bacterial culture and two ELISA techniques for the detection of Renibacterium salmoninarum antigens in salmonid kidney tissues. Dis Aquat Org 27:197-206

$>$ Karlesen F, Steen H, Nesland J (1995) SYBR Green I DNA staining increases the detection sensitivity of viruses by polymerase chain reaction. J Virol Methods 55:153-156

Kono T, Savan R, Sakai M, Itami T (2004) Detection of white spot syndrome virus in shrimp by loop-mediated isothermal amplification. J Virol Methods 115:59-65

Leon G, Maulen N, Figueroa J, Villanueva J, Rodriguez C, Vera MI, Krauskopf M (1994) A PCR- based assay for the identification of the fish pathogen Renibacterium salmoninarum. FEMS Microbiol Lett 115:131-136

Mackie TJ, Arkwright JA, Pryce-Tannatt TE (1933) Second interim report of the Furunculosis Committee. His Majesty's Stationery Office, Edinburgh

Magnusson HB, Fridjonsson OH, Andresson OS, Benediktsdottir E, Gudmundsdottir S, Andresdottir V (1994) Renibacterium salmoninarum, the causative agent of bacterial kidney disease in salmonid fish, detected by nested reverse transcription-PCR of 16S rRNA sequences. Appl Environ Microbiol 60:4580-4583

Mekata T, Kono T, Svan R, Sakai M, Kasornchandra J, Yoshida T, Itami T (2006) Detection of yellow head virus in shrimp by loop-mediated isothermal amplification. J Virol Methods 135:151-156

> Miriam A, Griffith SG, Lovely JE, Lynch WH (1997) PCR and probe-PCR assays to monitor broodstock Atlantic salmon (Salmo solar L.) ovarian fluid and kidney tissue for presence of DNA of fish pathogen. J Clin Microbiol 35: 1322-1326 
Moffitt CM (1992) Survival of juvenile chinook salmon challenged with Renibacterium salmoninarum and administered oral doses of erythromycin thiocyanate for different durations. J Aquat Anim Health 4:119-125

Mori Y, Nagamine K, Tomita N, Notomi T (2001) Detection of loop-mediated isothermal amplification reaction by turbidity derived from magnesium pyrophosphate formation. Biochem Biophys Res Commun 289:150-154

Mori Y, Kitao M, Tomita N, Notomi T (2004) Real-time turbidimetry of LAMP reaction for quantifying template DNA. J Biochem Biophys Methods 59:145-157

Mori Y, Hirano T, Notomi T (2006) Sequence specific visual detection of LAMP reactions by addition of cationic polymers. BMC Biotechnol 10(6):3

Nagamine $\mathrm{K}$, Watanabe $\mathrm{K}$, Ohtsuka $\mathrm{K}$, Hase $\mathrm{T}$, Notomi $\mathrm{T}$ (2001) Loop-mediated isothermal amplification reaction using a nondenaturated template. Clin Chem 47: $1742-1743$

Nagamine K, Hase T, Notomi T (2002) Accelerated reaction by loop-mediated isothermal amplification using loop primers. Mol Cell Probes 16:223-229

Notomi T, Okayama H, Masubuchi H, Yonekawa T, Watanabe K, Amino N, Hase T (2000) Loop-mediated isothermal amplification of DNA. Nucleic Acids Res 28:E63

Pascho RJ, Elliot DJ, Mallet RW, Mulcahy D (1987) Comparison of five techniques for the detection of Renibacterium salmoninarum in adult coho salmon. Trans Am Fish Soc 116:882-890

Pascho RJ, Chase D, McKibben CL (1998) Comparison of the membrane-filtration fluorescent antibody test, the enzyme-linked immunosorbent assay, and the polymerase chain reaction to detect Renibacterium salmoninarum in salmonid ovarian fluid. J Vet Diagn Invest 10:60-66

Pascho RJ, Elliott DG, Chase DM (2002) Comparison of traditional and molecular methods for detection of Renibacterium salmoninarum. In: Cunningham CO (ed) Molecular diagnosis of salmonid diseases. Kluwer Academic, Dordrecht, p 157-209

Powell M, Overturf K, Hogge C, Johnson K (2005) Detection of Renibacterium salmoninarum in Chinook salmon, Oncorhynchus tshawytscha (Walbaum) using quantitative PCR. J Fish Dis 28:615-622

Rhodes LD, Durkin C, Nance SL, Rice CA (2006) Prevalence and analysis of Renibacterium salmoninarum infection among juvenile Chinook salmon Oncorhynchus tshawytscha in North Puget Sound. Dis Aquat Org 71: 179-190

Savan R, Igarashi A, Matsuoka S, Sakai M (2004) Sensitive

Editorial responsibility: David Bruno,

Aberdeen, UK and rapid detection of edwardsiellosis in fish by a loopmediated isothermal amplification method. Appl Environ Microbiol 70:621-624

Scott R, Johnson K (2001) Inconsistency of Kirkegaard and Perry BKD ELISA antibody lots. Fish Health Newsl 29: $4-6$

Soliman H, El-Matbouli M (2005) An inexpensive and rapid diagnostic method of the koi herpesvirus (KHV) infection by loop-mediated isothermal amplification. Virol J 2:83

Soliman H, El-Matbouli M (2006) Reverse transcription loopmediated isothermal amplification (RT-LAMP) for rapid detection of viral hemorrhagic septicaemia virus (VHS). Vet Microbiol 114:205-213

- Starliper CE, Schill WB, Mathias J (1998) Performance of serum-free broth media for growth of Renibacterium salmoninarum. Dis Aquat Org 34:21-26

Suzuki K, Sakai DK (2007) Real-time PCR for quantification of viable Renibacterium salmoninarum in chum salmon Oncorhynchus keta. Dis Aquat Org 74:209-223

Teska JD (1994) In vitro growth of the bacterial kidney disease organism Renibacterium salmoninarum on a nonserum, noncharcoal-based 'homospecies-metabolite' medium. J Wildl Dis 30:383-388

Thai HTC, Le MQ, Vuong CD, Parida M and others (2004) Development and evaluation of a novel loop-mediated isothermal amplification method for rapid detection of severe acute respiratory syndrome Coronavirus. J Gen Virol 36:93-109

White MR, Wu C, Albregts SR (1995) Comparison of diagnostic tests for bacterial kidney disease in juvenile steelhead trout (Oncorhynchus mykiss). J Vet Diagn Invest 7:494-499

Wiens GD, Kaattari SL (1989) Monoclonal antibody analysis of common surface protein(s) of Renibacterium salmoninarum. Fish Pathol 24:1-7

Yeh HY, Shoemaker CA, Klesius PH (2005) Evaluation of a loop-mediated isothermal amplification method for rapid detection of channel catfish Ictalurus punctatus important bacterial pathogen Edwardsiella ictaluri. J Microbiol Methods 63:36-44

Yeh HY, Shoemaker CA, Klesius PH (2006) Sensitive and rapid detection of Flavobacterium columnare in channel catfish Ictalurus punctatus by a loop-mediated isothermal amplification method. J Appl Microbiol 100:919-925

Yoda T, Suzuki Y, Yamazaki K, Sakon N, Aoyama I, Tsukamoto T (2007) Evaluation and application of reverse transcription loop-mediated isothermal amplification for detection of noroviruses. J Med Virol 79:326-334

Submitted: February 26, 2008; Accepted: June 5, 2008

Proofs received from author(s): July 24, 2008 